\title{
An Ethical Investigation into the Impact of Mophane Worm Depletion on the Environment in the North-Eastern Part of Botswana: A Case Study of Gungwe and Mbalambi Villages
}

\author{
by
}

\author{
Fatima Selaledi
}

\section{ABSTRACT}

Mophane worm is a name given to caterpillars hosted by the Mophane tree. The mophane worm is harvested as food supplement in most of the Southern African countries. For the past few years, there have been some reports indicating that the worm has disappeared in some parts of Botswana. Hence, the aim of this research study has been to investigate from an ethical perspective the impact of mophane worm depletion on the environment. A qualitative approach was used in this study and data was collected from the following target groups of people: villagers, headmen of the stated two villages and the Ministry of Environment, Wildlife and Tourism (MEWT) officers both at local and national level. The theoretical framework involved traditional theories (i.e., Value Theory and Utilitarianism) and environmental ethical theories (i.e., Social Ecology, Environmental and Intergenerational Justice).

The research instruments employed were individual interview schedules, focus group discussions and observation. A fourfold model of analysis was used focusing on the biological, economical, social and political dimensions. From the findings of the study, it emerged that both natural and anthropogenic factors contributed to mophane worm depletion. The natural factors were drought and predation while the anthropogenic factors included massive usage of the host tree, destructive methods of harvesting and demand for more land for agricultural and residential purposes. It also emerged that mophane worm depletion had both negative and positive impacts on the environment. These included lack of money by the local people to buy their daily needs, lack of relish and poor livelihoods, loss of wildlife that fed on mophane worm and tension between government and local people over the regulation of the resource. Ethical evaluation revealed that the dominant value for the local people was utility value to the almost total lack of explicit awareness of intrinsic and inherent value, and that on utilitarian grounds, the overall evil that depletion of the mophane worm brought about outweighed its overall good effects. With regard to justice issues, the findings revealed that unjust social structures and injustices resulting from the unequal distribution of benefits and burdens as well as from the lack of adequate participation by the local communities in decision-making had a greater negative than positive impact. Finally, recommendations were made emphasising the utmost importance of government intervention to mitigate, if not, stop the depletion of the mophane worm. 


\section{INTRODUCTION}

Botswana, just like the rest of the world, finds itself at a time when nature is progressively being impoverished by loss of different species from the smallest insect to the biggest animal, such as the black rhino. As such, depletion impacts negatively on the entire environment. Its effects are not only being felt now but will also be felt in the distant future. There are several reasons as to why different species should not be allowed to become extinct: some are on account of their use value to humanity or the economic value derived from them; others are because of the moral consideration due to them as part of the biosphere and as having a 'good-of-their-own' to flourish and reach their full potential. Different species need to be preserved for the sake of their aesthetic and intrinsic value as well as for their instrumental value. All living things form part of the ecosystem. They are the living components of the ecosystem and their extinction is likely to be disruptive to the entire ecosystem. Many people see insects like moths' larvae or caterpillars as pests which need to be wiped out by insecticides because they just defoliate their host shrubs. But they fail to recognise the major roles that such insects play in the health of the ecosystem, or the benefits that can be derived from the same caterpillar by various dimensions of the environment, e.g., the biophysical benefit in relation to other animals. Furthermore, these insects benefit the socio-economic system by contributing to a traditional delicious meal as relish as well as to generating income (Barcalow, 1998; Beauchamp, 1982; Chiras, 1985; Goodpaster, 1999).

\section{STATEMENT OF THE PROBLEM}

The depletion of different species is not a problem that is confined to Botswana alone or to countries in Southern Africa. It is a problem for the whole world. The world is losing different species at a rate which has been under-estimated. In Botswana, one such species which is most likely to face extinction if no proper measures are put in place is the mophane worm. The mophane worm is both an income generating natural resource as well as a food supply because of its nutritional value. If such a resource were to be sustained, it could reduce high levels of poverty, especially among the rural area dwellers. However, something seems to have gone wrong as this once abundant edible worm has become reduced in population. Some authors have reported the disappearance of the worm in some parts of Botswana (Akpalu, Muchapodwa and Zikhali, 2007; Maviya and Gumbo, 2005). Although many studies on mophane worm have been carried out in Botswana and elsewhere, none of these studies have tackled the problem of mophane worm depletion and its impact on the environment. There is only scanty documentation on the disappearance of mophane worm in Botswana which is based on unconfirmed reports. Hence, there is little or no knowledge on the state of mophane worm at present in Botswana. It is for this reason that this study was carried out to ethically investigate the impact of mophane worm depletion on the environment in the North-eastern part of Botswana. 


\section{Aim}

The aim of the study was to investigate from an ethical perspective the impact of mophane worm depletion on the environment in the North Eastern part of Botswana.

\section{Specific objectives of the study}

(a) To highlight the different values related to the mophane worm;

(b) To identify the factors that led to mophane worm depletion in Gungwe and Mbalambi villages.

(c) To identify Botswana government policies on mophane worm sustainability;

(d) To make an ethical evaluation of mophane worm depletion; and

(e) To come up with recommendations for protecting the mophane worm from extinction in Botswana.

\section{METHODOLOGY}

The methodology of the study was qualitative involving ethical evaluation. The research was based on a case study design as it focused on the two villages of Gungwe and Mbalambi. It is also based on purposive sampling as a non-probability sampling method. Through the use of snowball sampling as a type of purposive sampling, the villagers were interviewed, harvesters of the edible mophane worm, the Chiefs or Headmen of the two villages, and the Ministry of Environment Wildlife and Tourism (MEWT) officers at local and national level. The sample size comprised of a total of fifty-six respondents (56), with nineteen (19) being males and thirty-seven (37) females. Data involved secondary and primary sources. Secondary source data was obtained from relevant literature at the University of Botswana main library, the University of Zambia library and the Department of Biological Sciences at the aforementioned universities. A variety of journals, newspapers and other articles were also accessed from the internet. Primary data was collected through the use of interviews, observation and focus group discussions. The findings were accordingly analysed and subjected to a comprehensive ethical evaluation through the application of relevant traditional and environmental ethical theories.

\section{Environment}

The word environment has many different definitions. It is necessary for purposes of this research to adopt a single definition. Therefore, this study is based on a model developed by O'Donoghue and discussed in Roux (2001: 18-19). This model looks upon the environment as something that is based on 'four related dimensions: biophysical, economic, social and political' as seen in the figure below. 


\section{Figure 1: O'Donoghue's Model of Environment}

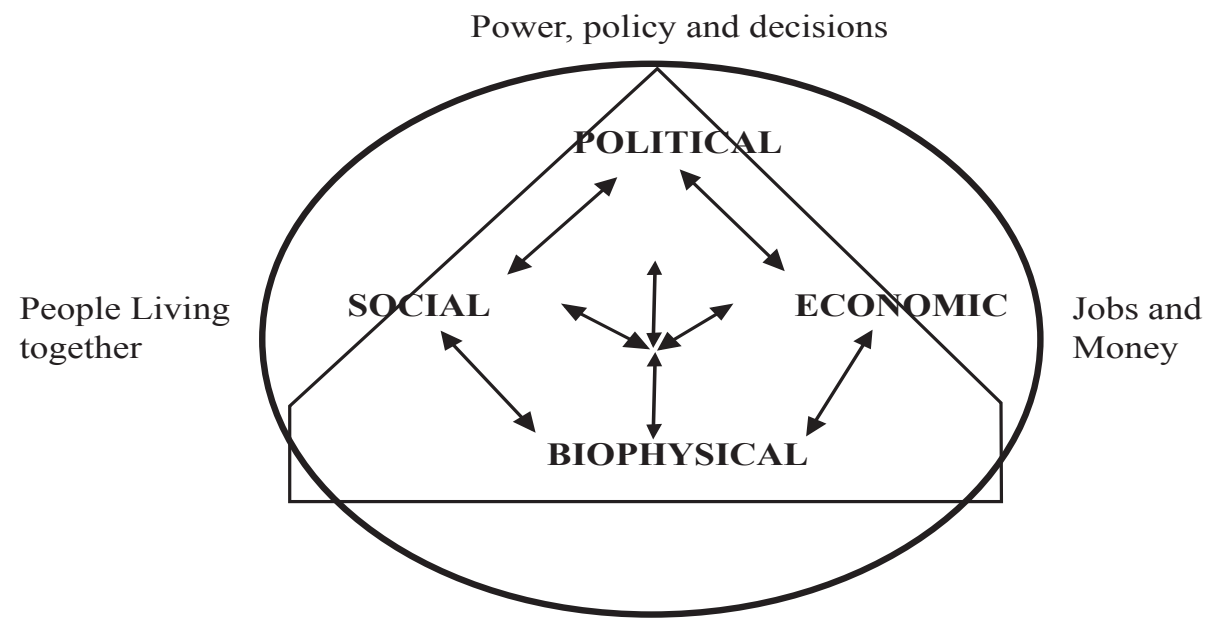

Living things and life support systems

Source: Roux, 2001: 19

As can be seen from the model, the biophysical (living things and life support systems), economic (jobs and money), social (people living together), and lastly political (power, policy and decisions) dimensions are interlinked.

\section{Overview on Mophane Worm in Botswana}

Botswana is also very concerned of the rate of biodiversity loss around the world which is happening at such an unprecedented rate. Some of these losses are due to long term results of natural processes like climate change, but others result from human activity. These anthropogenic factors can impact negatively on the functions of the ecosystem and, consequently, on the livelihoods of people. Due to limited knowledge of how the ecosystem operates and the future implications of species extinctions and changes in biodiversity levels, the need to take precautions as a nation is emphasised. In particular, Botswana and other Southern African countries should be concerned about the loss of an important veld product called mophane worm. The mophane worm is found and consumed in most of the Southern African countries such as Botswana, Namibia, South Africa, Zambia and Zimbabwe (Akpalu et al., 2007; Banjo, 2006).

In Botswana, there are only two popularly edible types of the mophane worm. One type has many colours, among them black, a bit of green, yellow, white and red, and a thorny protruding spine, technically known as Imbrasia belina or GoImbrasia belina (Akpalu et al., 2007). On the other hand, Roodt (1992: 52), gives the following description of the same type of mophane worm, 'the caterpillar is spiny hairless, about $7 \mathrm{~cm}$ and brightly coloured with red, yellow and black'. The other type is a green worm with a faint white dotted line which, when dried, becomes yellow in colour. It is locally known as phane e tala and technically known as Gynanisa maja. 
Mophane worm is a delicacy in Botswana. Dzimiri (2010: 17) writes that the "mophane worms have become a delicacy of choice in Botswana'. On a similar note a survey carried out by FAO in 2004 has revealed that 91 per cent of the participants that consume caterpillars were from Botswana. Most of the studies that have been carried out have revealed that the worm has high nutritional value as compared to most types of relish consumed in some of the Southern African countries. For example, the Department of Forestry and Range Resources (DFRR, 2009) in Botswana undertook a research on mophane worm's nutritional value as compared to beef, bilton and chicken. The results were as shown in the table below.

Table 1: Mophane Nutritional Value

\begin{tabular}{|l|c|c|c|c|}
\hline \multicolumn{6}{|l|}{ Comparison of Nutritional Quality (\%) } \\
\hline Sample & Protein & Fat & Carbohydrates & Calcium \\
\hline Phane & 56.8 & 16.4 & 13.8 & 0.458 \\
\hline Beef & 22.6 & 8.0 & 0 & 0.016 \\
\hline Bilton & 55.4 & 1.5 & 0 & 0.016 \\
\hline Chicken & 20.5 & 6.5 & 0 & 0.010 \\
\hline
\end{tabular}

Source: DFRR, 2009

These figures reveal that mophane worm (phane) has far more proteins than beef and chicken which are the kinds of relish mostly eaten in Botswana. In terms of carbohydrates, the mophane worm has 13.8 per cent as compared to 0 per cent of all the three types sampled above. It is even higher in fats as well as in calcium. All this shows that the mophane worm is an important veld product that needs to be preserved. A very distinctive social aspect about the harvesting of mophane worm is that, it is mostly done by women. Some scholars such as Moruakgomo (1996), reveal that women constitute 95 per cent of harvesters in Botswana and that most of them do not have reliable sources of income. In a gendered socio-economic study of phane done by Letsie (1996), she also states that most of the veld products including mophane worms are harvested by women because it is considered a female activity. She further points out that "rural women in Botswana are among the most socio- economically marginalised groups and a natural resource that offers the potential for improvement of their condition ought to be protected' (ibid.:118).

\section{RESEARCH FINDINGS, DISCUSSION AND ANALYSIS}

The focus of the study was to collect data with regard to the depletion of the mophane worm in Gungwe and Mbalambi villages. These findings are based on personal observation and the information obtained from individual interviews and focus group discussions (FGDs). Those in interviews will be referred to as "interviewees" whereas those in FGDs will be referred to as "participants". While the headmen and MEWT officers were at ease with interviews, villagers were more at ease in FGDs. 


\section{Observation}

No mophane trees were defoliated during the month of April, the time when there is usually defoliation due to the second batch of mophane worm being harvested. The vegetation looked green and thickened. The mophane trees also had fruits hanging from their twigs.

In September, both the leaves and seeds were falling off the trees and being blown by the winds. The seeds were also split open due to the heat and being buried by the blowing winds. It was also observed that the domestic animals were browsing on the green mophane leaves in April while in September the animals were now picking the falling dried leaves from the ground. There were no birds or wild animals seen during the researcher's stay in the two villages. There were a lot of brownish ants in the two villages which gave the researcher a hard time by climbing on the bed and biting on the ears and on the head of the researcher. They got into the food and were nearly everywhere. In all the households visited, none of the residents had mophane worm as relish but only the village chicken, garden vegetables, goat meat and beef sold from the vehicles passing through the two villages. In the households, it was also observed that there were more women than men in both villages. According to observation, there was significant evidence that the mophane worm had gone through a serious depletion in the two villages.

\section{Knowledge on Mophane Worm}

Participants in FGDs agreed in general that the mophane worm was an edibledelicious worm of which two varieties exist. They described them as follows: the green variety, which they refer to as phane ya mengwe in Ikalanga, and the black variety with many other colours known as shonja le mmiwa. According to the participants in Gungwe village, phane ya mengwe is said to have been named after Chief Mengwe of Maitenngwe or Ka Menngwe village in the central district of Botswana where the worm used to be in abundance. The shonja le mmiwa is known as such because of its thorny (mmiwa) spine. All the forty-eight (48) interviewees from both villages said that both of these worms used to be found in abundance in Gungwe and Mbalambi villages, though the green one was not as plentiful as the thorny one. It was also stated that these worms came from a very big butterfly that laid eggs on the mophane tree. The worms then grow from tiny little worms to very big edible worms. The ones not harvested burrowed themselves (kuyenda nsumbe) and turned into what they call zwigogoro (pupae) which, if not disturbed, will emerge after rainfall as big butterflies to lay eggs again.

\section{Harvesting of the Mophane Worm}

All four FGDs acknowledged that almost every household in the two villages was once involved in this seasonal activity year in and year out. All the fifty-six interviewees said that either themselves or their family members were once involved in the harvesting of the mophane worms. There were only two exceptional cases, one in Gungwe and 
the other in Mbalambi, where both women admitted to having a phobia about the worms. However, they stated that their families had been involved in the harvesting of this veld product.

\section{Common Harvesters of the Mophane Worm}

All the interviewees were unanimous in stating that the common harvesters had always been the women. One of the reasons given by the villagers, both male and female, was that it has always been the traditional role of a woman, and of a girl child especially that they had to provide for their families with relished shadza (porridge). In emphasising this, one male villager in a focus group discussion in Gungwe said that it had always been a woman's task and as men go out hunting, women go out gathering wild vegetables and wild berries. The women were also expected to gather different insects like the mophane worm. David Mabalane one of the male respondents in Gungwe village asserted that women had to be the ones to harvest the worms because, in more recent times, men have always been the ones going to work in the mines or towns. He also said that women have time to sit down to remove thorns in each other's hands and even nurse their lacerated hands whereas it would be quite embarrassing for a man to be seen doing the same. During an FGD at Gungwe, it was mentioned that the issue of harvesting and processing of the mophane worm entails a lot of work in terms of the harvesting and processing. Now that the worms are no longer there in their area, during harvesting time they need to relocate to places where the mophane worm is found in abundance.

\section{Benefits of the Mophane Worm}

Even though there could be challenges associated with the harvesting of this veld product, there are also some benefits associated with it. Participants in the FGDs from the two villages gave several reasons for harvesting the worms and for the roles played by the mophane worm. Firstly, as part of relish, it was stated that it was a nutritious kind of relish. All agreed also that people benefited economically through the selling of the worm which generated income to buy household resources. During an FGD in Mbalambi, participants also revealed that the mophane worms are also food for some animals like the chameleon, different birds, snakes and big lizards. Even some domestic animals are said to like them when cooked. During one of the FGDs at Gungwe, it was stated that by the worm defoliating the mophane tree, it helped them to get firewood because some of the branches would have completely dried.

\section{The Phenomenon of the Mophane Worm Depletion}

Most of the interviewees in the two villages, including the MEWT officers, were acutely aware of the depletion of the mophane worm in their areas. Some said that the worms were now sparingly found while others even said there were no longer any mophane worms found in their area at all. According to Gungwe and Mbalambi 
villagers, they have not had any mophane worm harvest for a period exceeding three years. Their opinions and views on mophane worm depletion were based on over ten years of residence in the study area and many of those interviewed were elderly people who had stayed in the village from childhood. This was confirmed by the Chiefs of both villages, as well as by the MEWT officer at the Headquarters of the North-east District in Masunga. The Chief clearly stated that the worms had become seriously depleted in the past few years in that area. Forty-nine of the fifty-six interviewees mentioned a time frame of between two to ten years. Six MEWT officers at national level were not sure of the state of the mophane worm in the North-eastern part of Botswana. A MEWT officer at (DFRR) also said that the mophane worm was still in abundance but was likely to be endangered in the future due to commercialisation. Some of the villagers were of the view that the mophane worm had gone for good or has faced total extinction whereas the local MEWT officer stated that a decline had been observed since 2008. The Chief of Mbalambi village was more specific when he said:

The worms have been disappearing since 1970. I remember very well. There were some intruders who invaded our forests at the far corner of the village at that time. Due to the way they harvested, our forests never recovered. I observed that since that time, the worms have been reducing in number until lately when they have completely disappeared.

It should be noted that all of those interviewed had lived in the area for over fifteen years and that many of them were old people who had lived in the two villages since birth or for most of their lives. The results of this study clearly indicate that the problem of mophane worm depletion does exist in Gungwe and Mbalambi villages in the North- eastern part of Botswana. Hence, the findings of this study have confirmed the reports on mophane worm depletion as noted by authors like Akpalu, et al. (2007), and Maviya and Gumbo (2005). Akpalu et al. (2007: 2), had already stated that, 'there have been reports of disappearance of the worms from parts of Botswana and South Africa'. Toms and Nonaka (2005) have also noted that there are some areas where the harvest appears to be very low and in some cases, local extinctions have occurred. Furthermore, Ghaly (2009: 94) has made a similar observation stating that 'these worms are facing mass extinction due to drought and overharvesting'. Banjo (2006: 299), also stated that, due to the popularity of the worm, 'it is eaten into extinction by people in Southern Africa.'

\section{Factors Leading to Mophane Worm Depletion}

Several factors, both natural and anthropogenic, emerged as the causes of mophane worm depletion in the North-eastern part of Botswana. The findings confirmed those of Ghaly (2009) a study carried out in Zambia which revealed that both natural and anthropogenic factors contribute to such kind of a phenomenon. 


\section{(i) Natural Factors}

Research has revealed that lack of rainfall resulting in drought is one contributing factor to mophane worm depletion. This is in line with Ghaly (ibid.:102) that 'the industry is faced with several problems including droughts that have devastated the harvest on a regular basis'. Similarly, the BSAP report done in Botswana has also reported that a lot of biodiversity loss is due to natural factors like climate change. Toms and Thagwana (2003b) noted the dried out remains of dead caterpillars and concluded that natural factors like lack of rainfall, hot sun accompanied by hot temperatures killed the hatched little worms.

The local community said that apart from rainfall and drought, there were some animal species that invaded their region. One such animal is a small brown ant known as (lemenyu) in Ikalanga. The ants are brownish, wingless and like moving in a trail. The so-called ant has greatly increased in the area and is everywhere, even in houses or huts, and there seems to be no other species that can consume this ant in order to keep the balance in the environment. This confirms the findings of Wootton (1984:126) that 'even those ants that nest on the ground, such as the mound-building wood-ants (formica), restlessly forage high up in trees in search of caterpillar larvae which they milk'. He also states that 'most animals, small and large, avoid these fierce hunters as they advance in vast spreading columns' (ibid: 127). He further asserts that 'these carnivorous ants colonies may run into millions ... as many as 20 million, and the availability of insects and other small animals, prey must be quickly exhausted by their demands' (ibid). This is a clear indication that these ants are one of the major contributing natural factors leading to the depletion of mophane worm in Gungwe and Mbalambi. Some villagers reported that, since the outbreak of the same ants, the mophane worm population in their region has drastically dropped. On a more general level, Wenz (2001:126) has noted that one of the main factors that cause species extinction is the introduction of exotics as he explains:

Exotics are species brought into an area by human beings, either deliberately or accidentally. Exotics can cause species extinction because ecological competition is a bit like commercial competition among companies trying to use the same raw materials, employ the same workers, and/or attract the same customers. Exotics, which often have no natural predators in their new home, often out-compete native species, reducing their fitness and possibly, leading to their extinction.

Wenz's explanation about exotics best suits the situation of the ants (lemenyu) which have invaded the villages of Gungwe and Mbalambi, especially as the villagers mentioned that there is no animal that eats these ants.

\section{(ii) Anthropogenic Factors}

The anthropogenic factors that emerged from the in-depth interviews and FGDs were as follows: unsustainable methods of harvesting, over-harvesting 
or over-exploitation, commercialisation, cultural beliefs on mophane worms, demand for land, and extensive usage of the host tree. With reference to the commercialisation of the worm as one of the contributing factors to mophane worm depletion. Ghaly writes that "over exploitation has led to local extinctions in several areas" (2009: 102). This is, in fact, an indication that these worms are highly endangered and are likely to face extinction in the near future. Some people harvest in a most destructive way by cutting down the trees or branches infested by the worms. A similar observation was made by Mbata and Chidumayo (2003) who noted that some people in Zambia would clear the land by cutting down up to two hectares trees especially at a time when caterpillars are in abundance. Akpalu et al. (2007), have also alluded to the fact that the worms have declined due to over-exploitation and lack of selective harvesting. The research findings have revealed that the high demand for land for agricultural purposes and residential plots has had an impact on the loss of habitat for the mophane worm. The villagers stated that there is massive usage of the host tree in their area, especially for household purposes. Similarly, Toms and Thagwana (2003b) have identified other factors due to human activity like the loss of habitat as one of the main threats to biodiversity. Such habitat destruction is mostly due to the construction of houses, roads and other forms of infrastructure. A similar instance is reported by Marais (in Gashe et al., 1996) who says that, in Namibia, the trunk bark and branches of trees are commonly used in the construction of villages, stock and crop enclosures. Furthermore, according to Mogotsi (2009), the mophane tree is used for fuel, as fodder for livestock, as timber for traditional huts or making utensils and due to its wide spreading canopy, for providing shade. Hence, the cutting down of trees could have an enormous impact on the population of insects found in an area. For example, Vantomme et al. (2004) noted that bush fires may also lead to deforestation which may, in turn, result in destruction of the insects and, hence, lead to population decline. Hara (2006) has also mentioned that the chitemene "shifting cultivation" land use practice, which results in loss of desirable tree species and on which caterpillars feed on also results in depletion of the mophane worm.

\section{Impact of Mophane Worm Depletion}

The depletion of the mophane worm in Gungwe and Mbalambi villages has resulted in both negative and positive outcomes on the environment. The impact has been felt in the four dimensions of the environment as per O'Donoghue's model in Figure 1:

(a) the biophysical;

(b) economic;

(c) social; and

(d) political. 


\section{(a) The Biophysical Environment}

(i) Negative Impact

Due to the depletion of the mophane worm, the natural environment has been affected both negatively and positively. The negative impact is felt in the loss of certain types of wildlife, the loss of manure and the scarcity of firewood. All the forty-eight villagers stated that, in the past, there were a lot of different kinds of small animal species which fed on the worm. Such animals included different kinds of birds, such as the vultures, crows and guinea fowls, chameleons, snakes, different forms of lizards and squirrels. Now, they have become few. Different kinds of livestock are said to be feeding on the mophane worm and, although most of the domestic animals prefer it boiled in salty water as do humans, they still eat them.

The loss of manure was also identified as a negative effect. The villagers explained that the droppings of the mophane worm acted as manure for the soil and for the growth of different kinds of plants. The local MWET officer, confirmed that the droppings have nitrogen which is needed by the soil, and that these droppings act as feed to small organisms in the soil as well.

The villagers further stated that the worms defoliated the mophane tree resulting into some branches becoming dry enabling people to get firewood easily. This was especially important because recently policies had been put in place that deny people permission to cut live trees making life difficult as they do not have any other means for cooking. Of course, it has to be noted that what the villagers perceive as impacting negatively on them by forbidding the cutting down of trees is based on an anthropogenic utilitarian ethical evaluation.

\section{(ii) Positive Impact}

The depletion of the mophane worm has in some ways also benefited the biophysical environment. Two villagers, one from Mbalambi and another from Gungwe, noted that it was for the better that the worms have disappeared. One villager in Gungwe said a lot has changed, 'the worm severely reaped the forest naked and, since it disappeared, their land is green and the mophane trees are now able to bear fruits' (Gonyana la ka be le mbula shanngo kwa ka bepa kubi, chinnga kwa la ka yenda shanngo e tala e bile mepane ena bana). She went on to explain that with the mophane worm, the tree now has a chance to bear fruit and flourish, and that when these fruits dry, they drop off the trees, get buried and new shrubs emerge.

Another participant in Mbalambi, has a phobia of the worm, said that their livestock, goats and cattle, now have something to feed on because they used to compete for the same tree with the mophane worm. What was happening was that the mophane worm would feed at night, and by dawn, 
the tree would be completely defoliated so that the rest of the animals would suffer. In this way, the depletion of the mophane worm was perceived to impact positively on the biophysical environment especially as the host tree was given a chance to flourish and produce seeds and thereby allow other animals to feed.

\section{(b) The Economic Environment}

All the forty-eight participants stated with disappointment that the disappearance of the worm has been a serious challenge to their finances. The villagers revealed that, with the selling of the worms, they managed to meet some of their basic needs because their area had very scarce job opportunities. One respondent in Gungwe said that she used to sell a 50kg bag at P400.00 (ZMK 280,000) and that a mug would sell for P5.00 (ZMK 3,500). One of the villagers in Mbalambi who runs a kiosk revealed that the depletion of the worm had affected her business as the worm was one of the commodities that generated a lot of profit for her.

\section{(c) The Social Environment}

Under the social dimension during a FGD, the participants lamented that their way of life had been badly affected as it was part of their culture to harvest the worms and that they used to pass on this skill to their children. All the fortyeight participants stated that the worm was also a form of relish, and that its disappearance had led to problems as other forms of relish such as beef and chicken are expensive and scarce in their area. One of the villagers in Gungwe said that the worms helped in boosting their immune system, especially for those who could not afford other forms of food. However, one of the male villagers in a FGD complained that during the harvesting of mophane worms, some women neglected their fields and abandoned their children. Another social dimension was involving reverence to the deity. The Headmen of Mbalambi, and two old women who believe in Mwali, suggested that, as villagers, it is time for them to go back to the mountain (dombo) to apologise on behalf of all who have been involved in behaviour destruction to the environment so that the mophane worms might come back.

\section{(d) The Political Environment}

According to all the eight MWET officers, there had been a policy on the regulation of some natural resources which was implemented in 2006 and included the mophane worm/Imbrasia belina). In 2007, however, the regulation was amended to exclude it under category $C$. This has caused much dissatisfaction and confusion as it was not clear as to why this change was made. It resulted in tension between the villagers and their government. One villager in Gungwe, complained that the government of Botswana is just imposing on them one 
policy after another without even consulting them on issues affecting them. All the participants, including the Headmen of both villages, said that they just heard through rumours that no one is allowed to harvest the mophane worms without a permit. One of the participants in Gungwe, revealed that she heard the news from her daughter in Palapye. Her daughter had been among a group of harvesters who were confronted by some officials from the surrounding area for harvesting the worms without a permit. None of the interviewees were even aware of the withdrawal of the regulation in 2007. However, during a FGD, some male participants reported that they had recently been informed of a new regulation on the use of mophane tree. They said the Land Boards officials had informed them that whoever would be caught cutting down the mophane tree would be subjected to a sentence in prison or fined. They complained that as their lives revolved around their immediate natural environment, especially around the mophane tree, they did not know how the government was expecting them to survive when it was not even providing alternatives for them to alleviate poverty. While one MWET officer at national level thought the withdrawal of the regulation had been politically motivated as the government had later realised that it was a wrong move to have implemented it without having consulted the local inhabitants on something that involved them. Those interviewed also revealed that if they had been involved in the decision-making process, they would have come up with better decisions because they had better knowledge about their environment than the government officials. The MWET local officer was also of the view that the local community should be involved in issues such as the conservation and protection of the natural resources or veld products within their territory.

The Headmen suggested that a permit for harvesting should only be granted to those who are harvesting in bulk, and that permission should be obtained from the Chiefs/Headmen and not from the government officials. According to them, the Chiefs/Headmen should be granted authority over their immediate environment. This would help them to always be on the lookout for intruders, especially the illegal immigrants who cross over to destroy their environment. They said that, if given the resource use rights as in other areas where there is wildlife, it would help to improve their lifestyle as well as manage the natural resources well. The MWET officer also suggested the implementation of Community Based Natural Resource Management (CBNRM) policies and the formation of conservation trusts by the villagers as is the case in other areas where there is a lot of wildlife could help in empowering the local community.

The general opinion of those interviewed was that the government must help in re-introducing the mophane worm in their area and in setting up harvesting quotas. People should be monitored when harvesting so that they would not be allowed to roast the worms in ashes. They also suggested that the government should dig some of the pupae from the area where the mophane worms are still found in abundance and bury them in their region where they will emerge as 
butterflies to lay eggs. They said that, if given the opportunity and taught farming technology, they could be involved in the rearing of the worms. They further stated that it is not only the elders who should be sensitised on environmental sustainability during village gathering but even children in schools.

Finally, most of those interviewed were of the view that everything that they had accessed to today should be conserved for future generations as they were entitled to them as much as they were. They said that they needed to leave some food for the future generations. One of the villagers in Gungwe, added that it would be very much unfortunate for their great grand-children to just see the mophane worm in pictures. Furthermore, the worm might be found in future to be more valuable in a lot of ways that they were not aware of now. The MWET officer at national level was of the same opinion in that he indicated that there was need to conserve the mophane worm for the future generations. He said that was why they were embarking on different studies in order to determine the level and utilisation of the worm. He also said that the government was in the process of developing regulations to govern harvesting and of come up with strategies to ensure sustainable harvesting by the local communities.

\section{ETHICAL EVALUATION}

\section{Value Theory}

Values are at the root of ethics. Values identify the worth of something, and that worth can be judged to have utility, intrinsic or inherent value. Of course, an object can be judged to have all the three kinds of values depending on what was under consideration. For example, in the case of the mophane worm, the utility value would be identified with reference to its usefulness to humans, animals or the ecosystem. According to the findings, the villagers harvested mophane worms only for consumption and commercial purposes. This contributed to better or improved livelihoods of the rural area dwellers. Respondents in both villages indicated that the mophane worm was valuable to them because it improved their way of life, especially as an income generating commodity. The mophane worm, therefore, is of utility value to the local community. Some members of the local community also revealed that, due to its high nutritional value, it was very good in boosting their immune system. On the other hand, the villagers indicated that they did not harvest the entire mophane worm but left some in order to pupate. However, this action was not done for the purpose of letting it flourish or for a good-of-its-own but for utility value as they revealed that they spared them for the sake of another yield.

\section{Utilitarianism}

Utility value is highlighted in utilitarian theory or utilitarianism. Utilitarianism is a traditional ethical theory that states the rightness or wrongness of an action based on the outcome of such an action. For utilitarian's, 'the rightness and wrongness of actions 
and practices are determined solely by consequences produced for the well-being of all parties affected by the actions or practices' (Beauchamp, 1982: 73). Therefore, based on such an argument, one could say that the acts the harvesters were involved in, which resulted in the depletion of the mophane worm, did not produce or lead to the maximisation of good consequences because the results of the depletion of the mophane worm have impacted negatively on the four dimensions of the environment. Taking into account the overall consequences brought about by the depletion of the mophane worm, they are bad rather than good. In the biophysical environment, the result has been a loss of wildlife with regard to the different kinds of birds that feed the mophane worm. Furthermore, the very livestock that feed on the host tree and eat the worm are being deprived of nourishment. Again, there is loss of nitrogen in the soil which the mophane worm adds by its droppings. On the economic level, people have lost the income earned through selling of this veld product with its consequent negative effect on their livelihood as well as on the economy of the country as a whole.

On the social sphere, the people's way of life has been affected negatively because they are deprived of nutrition and relish, and are prevented from extending benefits of the mophane worm to future generations. The political dimension has also been negatively affected by generating tension between the government and villagers. Although some good consequences have been identified to result from the depletion of the mophane worm, namely, in that the host tree can reach its full potential by bearing fruits for reproduction, in that defoliation by the mophane worm is avoided, and in that wildlife and livestock have fodder to feed on, nevertheless, from the utilitarian perspective, the action that results in the depletion of the mophane worm is, on balance, an ethically wrong action because the negative effects outweigh the positive effects. Still more the depletion of the mophane worm does not improve the well being of the villagers and neither does it maximise the good of all the affected parties.

However, while the utilitarian value seems to dominate, there is also evidence of the acknowledgement of both intrinsic and inherent values as well. For example, one of the villagers in Gungwe, narrated that her son-in-law from the southern part of the country, once visited them in December 1998 when the worm was in still abundance. She recalls seeing him holding a twig with the worm clinging on to it. He looked at the worm in admiration and then put it back on to the mophane tree. This could suggest that even if the villagers did not explicitly express their appreciation of the beauty and complexity of the worm, the stranger who was seeing this worm alive for the first time, was able to wonder at it and appreciate its inherent value. Furthermore, putting it back on the tree, and not killing it, the stranger seemed to accept its intrinsic right not to be harmed without good reason. Intrinsic value refers, first of all, to the worth of a living being in-itself and for-itself, a value that expresses itself in the living being striving to survive and flourish in seeking its own organic good.

In this context, one type of the mophane worm found in Botswana has thorns or a spike spine which is undoubtedly an evolutionary defence mechanism that developed over the years. It should also be further noted that African cultures acknowledge the intrinsic value of things by showing respect to "spirits" living in them and giving life 
to them. The fact that a shrine to Mwali has been constructed in Gungwe in relation to the natural environment which includes the mophane worm demonstrates the reverence and respect in which the mophane worm is held.

\section{Justice}

Traditionally, the concept of justice is about fairness among the human beings only. This has now been extended to the natural environment and future generations. In this article, justice was discussed under the following three theories: Social Ecology, Environmental Justice and Intergenerational Justice.

\section{Social Ecology}

Murray Bookchin, the founder of Social Ecology, believes that the exploitation of the environment is as a result of the inequalities that exist in the structure of human society. He notes in particular that social structural inequalities are rooted in forms of dualism. Bookchin emphasises that relationships in society are characterised by dualisms such as powerful/weak, male/female, rich/poor and urban/rural which identify one side as superior and the other as inferior. The role of mophane worm female harvesters can be seen to belong to this kind of dualism which is socially and culturally conditioned. Social Ecology blames the existence of hierarchically structured societies for the manner in which the natural environment is degraded. Due to poor educational and employment opportunities, the male villagers in Gungwe and Mbalambi have had to leave their villages to find work and the female villagers have little option other than to harvest the mophane worm for food and to pay school fees from the sale of these worms. According to Social Ecology, the solution to environmental degradation is first and foremost to dissolve the exploitative hierarchical social structures that exist in society. From this perspective, the depletion of the mophane worm, along with other forms of environmental harm, will continue in Botswana until a more de-centralised and democratic social structure is established.

The women and the girl child are the common harvesters of the mophane worm in Gungwe and Mbalambi villages. A reason given for this is that women are less educated than men in the area and hence are not employed. By custom and tradition, they are expected to remain at home while men migrate to the towns to look for jobs. The outcome is that they feel compelled to exploit nature for survival. They turn to mophane worm harvesting as one way of surviving. In a few cases, however, men become involved in the harvesting of mophane worm because they live in an area where there are no job opportunities. Participants in FGDs in both villages indicated that, traditionally, it is the role of a woman to provide food for her family. 


\section{Environmental Justice}

Environmental justice is of two forms: 'domestic' and 'global'. Domestic environmental justice, which is more relevant in this study, is concerned with the 'policies, laws and practices within the boundaries of a country', Wolf (2003: 427). In the case of mophane worm depletion, domestic environmental justice can be seen to relate to unsustainable harvesting methods and the use of the host tree.

\section{(a) Unsustainable Harvesting Methods}

Unsustainable harvesting or overharvesting is among the main human factors affecting the environment. It expresses itself in two ways: harvesting everything and not leaving any worm to burrow in preparation for the next harvest; digging up the ones that are burrowing or already buried under ground. These activities are an injustice done to the environment by the harvesters because they are disrupting the natural balance in the ecosystem and are failing to respect both the utilitarian and intrinsic values of the mophane worm. Furthermore, as villagers do not have user rights over the produce of the land, there is no control over exploitation of the mophane worm from intruders. This has been referred to as the 'tragedy of the commons', i.e., everyone having the liberty to use the land at will without any controlling authority. As the mophane forests are regarded as common property which is open to all, there is no protection for the mophane worm. Because the government has withdrawn user rights from the local people, it has resulted in contributing to depletion of the mophane worm. Hence, there is need for a policy which will entrust the people with the responsible care of their local environment. In other words, the solution would be to replace the system of the commons with a responsible system of control. The government of Botswana had come up with a policy to regulate the harvesting and utilisation of the mophane worm although, regrettably, they later on reversed it due to reasons best known to themselves.

\section{(b) Use of Host Tree}

The women in the two villages indicated that one of the main contributing factors to mophane worm depletion is the irresponsible usage of the host tree by men. They blame men for the excessive destruction of the host tree for roofing using it for supports, rafters and for making doors from the mophane tree. Men also sell the firewood, build kraals, poles for the field as well as crafting different household resources. Men are therefore seen to have contributed not only to the destruction of the environment but also to the depletion of the mophane worm due to loss of habitat. 


\section{Distributive and Participatory Justice}

Environmental justice also includes two further dimensions of justice, i.e., distributive and participatory. Distributive justice is concerned with the distribution of environmental benefits and burdens. According to the findings, the disadvantaged groups like rural area dwellers, the poor and the women are the ones who are now faced with greater burdens brought about by mophane worm depletion. Such burdens are manifested in the biophysical, economic, social and political dimensions.

Participatory justice is interested in how the distributive decisions are made and who participates in decision making. In 2006, the government of Botswana introduced a regulation on mophane worm harvesting and utilization as an intervention measure. The villagers denied any knowledge on the regulation and stressed the fact that they had not been consulted. In 2007, the regulation was reversed although once again, without any consultation with the local people. Although the government of Botswana under the Department of Forestry and Range Resources (DFRR), had come up with a regulation with regard to the harvesting and utilisation of the mophane worm, in the case of Mbalambi and Gungwe, they did not involved the local people in the decisionmaking process and this resulted in the lack of participatory justice relating to the environment.

\section{Intergenerational Justice}

Based on impact of mophane worm depletion, concern expressed was that the future generation might never see the mophane worm alive but only in pictures, most probably on the five pula coin. The importance of preserving the mophane worm for future generations was because the generation might need it more than the present generation. This view reflects the focus of Intergenerational Justice, a theory about the need to sustain resources for the sake of future generations. For example, the worm might result in medicinal breakthroughs in the future. Hence, an injustice would be done to future generations if the mophane worm was allowed to become extinct.

\section{CONCLUSION}

The study has revealed that mophane worm has become depleted in Gungwe and Mbalambi villages. Both anthropogenic and natural factors emerged as contributing factors to mophane worm depletion. Among the anthropogenic factors are unsustainable harvesting in the form of overharvesting and exploitation due to commercialisation, the methods used for harvesting, cultural beliefs, the demand for more land for agricultural and residential purposes, and extensive usage of the host tree. The natural factors are invasion by foreign species and lack of rainfall resulting in drought. The government of Botswana did not involve the local people in the decision-making process regarding mophane worm as most of them were not aware of the existence of any regulation or of its later amendment. Through the application of some traditional and environmental ethical theories, an ethical evaluation was made of the findings. The 
study finally concluded that the impact of the depletion of the mophane worm on the four dimensions (i.e., biophysical, economic, social, and political) has on utilitarian ethical grounds, been more negative than positive.

\section{RECOMMENDATIONS}

In view of the findings of this study and in order to mitigate, if not stop, the depletion of mophane worm, the following recommendations were made:

1. The government of Botswana should work closely with the local people in rural areas in making decisions that concern natural resources like the mophane worm because they have more accurate knowledge related to the immediate environment.

2. Further research is recommended to evaluate the extent of the impact of natural factors like exotic species on the environment, and how they could be dealt with or checked out in order to keep the naturally evolved balance in the eco-system.

3. The government should come up with intervention measures like the reintroduction through harvesting and the relocation of eggs of mophane worms to areas where they have become depleted or faced with possible extinction.

4. The engagement of monitoring systems such as harvesting quotas is needed in areas where the mophane worm is still found in abundance.

5. There should be community involvement in decision making especially by reinstating the user rights of local inhabitants, so that they can take responsibility for their use of the natural resources in their areas.

6. The government should send representatives to other countries (e.g., Mpika district in Zambia) where there is still an abundance of the mophane worm for benchmarking.

\section{REFERENCES}

Akpalu, W. Muchapodwa, E. and Zikhali, P. (2007), 'Can the restrictive harvest period policy conserve mopane worms in Southern Africa?' A bio-economic Modeling approach working Paper Number 65.

Allotey, J. and S. Mpuchane, (2003), 'Utilisation of Useful Insects as Food Source', African Journal of Food, Agriculture, Nutrition and Development (AJTAND), 3(2): 1-8.

Banjo, A.O. (2006), 'The Nutritional Value of Edible Insects in South-western Nigeria', African Journal of Biotechnology, Vol. 5 (3), pp. 298-301. Available at: http://www.academicjournals.org/AJB.

Barcalow, E. (1998), Moral Philosophy Theories and Issues. 2nd Edition. New York: Wadsworth Publishing Company.

Bayles, M.D. and Henley, K. (Eds) (1983), Right Conduct: Theories and Applications. New York: Random House.

Beauchamp, T.L. (1982), Philosophical Ethics: An Introduction to Moral Philosophy. New York: McGraw-Hill Book Company. 
Boff, L. (1994), 'Social Ecology: Poverty and Misery'. In Hallman, D.G. (Ed.), Ecotheology: Voices from South and North. Maryknoll, New York: Orbis Books. Bookchin, M. (1993), 'What is Social Ecology?' In Zimmerman, M.E. (Ed.), Environmental Philosophy. Englewood Cliffs, New Jersey: Prentice Hall.

Ministry of Environment, Wildlife and Tourism. Biodiversity Strategy and Action Plan: Revised, (2007), Gaborone: Government Print.

Botswana Department of Forestry and Range Resources (2009), Government Print, Gaborone.

Government Gazette (2006), Statutory Instrument No. 89 of 1 December 2006. Agricultural Resources Conservation Act, Government Print, Gaborone.

National Conservation Strategy, National Policy on Natural Resources Conservation and Development (1990), Government Paper No.1 of 1990, Government Print, Gaborone.

National Policy on Natural Resource (1990), Government Print, Gaborone.

Chidumayo, E.N. and Mbata, K.J. (2002), 'Shifting Cultivation, Edible Caterpillars and Livelihoods in the Kopa area of northern Zambia', Forests, Trees and Livelihoods, 12: 175-193.

Chiras, D.D. (1985), Environmental Science: A Framework for Decision-making. California: The Benjamin/Cummings Publishing Company Inc.

Ditlhogo, M. (1996), 'The Ecology of Imbrasia Belina (Westwood) in North-Eastern Botswana'. In Gashe, B.A. and Mpuchane, S.F. (Eds), Proceedings of the First Multidisciplinary Symposium on Phane, 18 June 1996, Department of Biological Sciences, UB/KCS, 46-68.

Dzimiri, N. (2010), 'The Rainy Season Reignites the Mophane Worm Craze', Sunday Standard, Newspaper, January, pp.10-16.

FAO (2004), 'Edible Insects, Important Source of Protein in Central Africa, Nutritious Income Generating, Biological Pest Control'. Available at: http://www.fao.org/ newsroom/en/news/2004/51409/index. htm (retrieved 20 July 2010).

Figueroa, R. and Mills, C. (2003), Environmental Justice. In Jameson, D. (Ed.), A Companion to Environmental Philosophy. London: Blackwell.

Frey, R.G. \& Wellman, C.H. (2005), A Companion to Applied Ethics. London: Blackwell. Gashe, B.A. \& Mpuchane, S.F. (Eds), Proceedings of the First Multidisciplinary Symposium on Phane, 18 June, 1996, Department of Biological Sciences, UB/ KCS, 104-121.

Ghaly, A.E. (2009), 'The Use of Insects as Food in Zambia', Online Journal of Biological Sciences, (4): 93-104, 2009 ISSN 1608-4217 Science Publications. Nova Scotta: Canada (retrieved 10 June 2010).

Goodpaster, K. (1999), 'On Being Morally Considerable'. In M.E Zimmerman (Ed.), Environmental Philosophy. Englewood, Cliffs, New Jersey: Prentice Hall.

Hallman, D.G. (1994), Ecotheology: Voices from South and North. Maryknoll, New York: Orbis Books.

Hara, E. (2006), An Investigation of Factors Influencing the Abundance of Edible Caterpillars in Kopa's Chiefdom, Mpika District, Zambia, Thesis (MSc), Unpublished MA Dissertation, University of Zambia. 
Jameson, D. (2003), A Companion to Environmental Philosophy. London: Blackwell. Keller, D.A. (2010), Environmental Ethics: The Big Questions. Oxford: Blackwell. Letsie, L. (1996), ‘A Gendered Socio-economic Study of Phane' In: Gashe, B.A. and Mpuchane, S.F. (Eds), Proceedings of the First Multidisciplinary Symposium on Phane, 18 June, 1996, Department of Biological Sciences, UB/KCS, 104-121.

Macala, J.P. (1996), 'Colophospermum Mopane: A Fodder Tree for Feeding Livestock'. In Gashe, B.A. and Mpuchane, S.F. (Eds), Proceedings of the First Multidisciplinary Symposium on Phane, 18 June, 1996, Department of Biological Sciences, UB/KCS, 104 - 121.

MacKinnon, B. (1998), Ethics: Theory and Contemporary Issues, $2^{\text {nd }}$ Edition: New York: Wadsworth Publishing Company.

Marais, E. (1996), 'Omaungu in Namibia: Imbrasia Belina (Saturniidae: Lepidoptera) as a commercial Resource'. In Gashe, B.A. and Mpuchane, S.F.(Eds), Proceedings of the First Multidisciplinary Symposium on Phane, 18 June, 1996, Department of Biological Sciences, UB/KCS, 104-121.

Maviya, J. and Gumbo, D. (2005), Incorporating Traditional Natural Resource Management Techniques in Conventional Natural Resources Management Strategies: A Case of Mopane Worms (Amacimbi) Management and Harvesting in the Buliliamamangwe district, Zimbabwe (retrieved 10 July 2010 and availalable at: http://www.jsdafrica.com/Jsda/Fall2005/ARCMopane\%20 Worms\%20Magmt.pdf

Mbata, K.J. (1995), 'Traditional uses of Arthropods in Zambia: I. The food insects', The Food Insects Newsletter, 8: 5-7.

(1999), 'Traditional uses of Arthropods in Zambia: II. Medicinal and Miscellaneous Uses', The Food Insects Newsletter, 12(2): 1-7.

Mbata, K.J., Chidumayo, E.N. and Lwatula, C.M. (2002), 'Traditional Regulation of Edible Caterpillar Exploitation in the Kopa Area of Mpika District in northern Zambia', Journal of Insect Conservation, 6: 115-130.

Mbata, K.J. and Chidumayo, E.N. (2003), 'Traditional Values of Caterpillars (Insecta: Lepidoptera) Among the Bisa People of Zambia', Insect Science and Its Application, 23(4): 341-354.

Mogotsi, K. (2009), Enhanced Learning and Delivery of Crop Science (CSP) Botswana College of Agriculture Curriculum, Department of Crop Science and Production, University of Botswana, Unpublished, GABORONE. Available at: http://www.prota.org/uk/About+Prota/ (Retrieved on 10 July 2010).

Moruakgomo, M.B.W. (1996), 'Commercial Utilisation of Botswana's Veld Products, The Economics of Phane: The Dimension of Phane Trade'. In Gashe, B.A. and Mpuchane, S.F. (Eds), Proceedings of the First Multidisciplinary Symposium on Phane, 18 June, 1996, Department of Biological Sciences, UB/KCS, 104-121. Northcott, M.S. (1996), 'The Turn to Nature'. In The Environment and Christian Ethics. Cambridge: Cambridge University Press.

North-east District Council: A Service Guide. Available at: www.mlg.gov.bw/nedc. 
Ohiokpehai, O., Bulawayo, B.T., Mpotokwane, S., Sekwati, B. and Bertinuson, A. (1996), 'Expanding the Uses of Phane, a Nutritionally Rich Local Food in Botswana'. In Gashe, B.A. and Mpuchane, S.F. (Eds), Proceedings of the First Multidisciplinary Symposium on Phane, 18 June 1996, Department of Biological Sciences, UB/KCS, 104-121.

Panneerselvan, A. and Ramakrishnan, M. (2005), Environmental Science Education.

New Delhi. Sterling Publishers Private Limited.

Roodt, V. (1992), Trees of the Okavango Delta and Moremi Game Reserve. Pretoria: Shell Publishers.

Roux, K. (2001), Environmental Education Processes Active Learning in Schools. Pietermaritzburg: University of Natal Press.

Sagoff, M. (1993), Population, Nature, and the Environment, Report from the Institute for Philosophy and Public Policy, Vol. 13, No. 4, p.10.

Sekhwela, M.B.M. (2007), Towards an Integrated Sustainable Harvesting, Management and Conservation of Phane and Mophane Woodlands, University of Botswana. Setshogo, P. and Venter, F. (2003), Trees in Botswana: Names and Distribution. In Southern African Botanical Diversity Network Report No. 18, Pretoria, South Africa.

Stamp, E.N. and Casey, M.T. (1993), Caterpillars Ecological and Evolutionary Constraints on Foraging. New York, London: Chapman and Hall.

Styles, C.V. (1996), 'The Biological Ecology of Imbrasia Belina (Saturniinae, Saturniidae) with Reference to its Behaviour, Physiology, Population Dynamics, Impact within Mopane Veld and Utilisation within South Africa'. In Gashe, B.A. and Mpuchane, S.F. (Eds), Proceedings of the First Multidisciplinary Symposium on Phane, 18 June, 1996, Department of Biological Sciences, UB/KCS, 104-121.

Teferra, G., Allotey, J., Mpuchane, S.F., Siame, A.B. and Gashe, B.A. (1996), 'The Nutrient Composition of the Leaves of Colophospermum Mopane and Sclerocarya Birrea; and their Quality as Food for Mophane Worms'. In Gashe B.A. and S.F. Mpuchane (Eds), Proceedings of the First Multidisciplinary Symposium on Phane, 18 June 1996, Department of Biological Sciences, UB/KCS, 104-121.

Toms, R.B., Thagwana, M.P., and Lothole, K.D. (2003), 'The Mopane WormIndigenous Knowledge in the Classroom: Science in Africa', Africa's Online Science Magazine (retrieved 13 January 2010): Available at: http://www. scienceinafrica.co.za/2003/june/mopane.htm.

Toms, R.B. \& Thagwana, M. (2003a), 'Eat Your Bugs', Science in Africa: Africa's First Online Science Magazine (retrieved 23 January 2010). Available at: http:// www.scienceinafrica.co.za/2003/october/stinkbug.htm.

(2003b), 'On the trail of missing mopane worm', First Online Science Magazine (retrieved 23 January 2010): Available at: http://www.scienceinafrica.co.za/2005/ january/htm.

Toms, R.B. and Nonaka, K. (2005), 'Harvesting of Insects in South Africa and Japan-Indigenous Knowledge in the Classroom: Science in Africa', Africa's Online Science Magazine (retrieved 13 January 2010). Available at: http://www. scienceinafrica.co.za/2005/August/mopane.htm. 
Vantomme, P., Gohler, D. and N'Deckere-Ziangba, F. (2004), 'Contribution of Forest Insects to Food Security and Forest Conservation: The Example of Caterpillars in Central Africa', ODI Wildlife Policy Briefing No. 3. Available at: http:// www.odi-bushmeat.org/wildlifepolicybriefs.htm. (Retrieved 13 January 2010). Warren, K. (1993), 'Introduction to [Ecofeminism]'. In Zimmerman, M.E. (Ed.), Environmental Philosophy. Englewood. Cliffs, New Jersey: Prentice Hall. Wenz, P. (2001), Environmental Ethics Today. Oxford: Oxford University Press. Wolf, C. (2005), 'Intergenerational Justice'. In Frey, R.G.and Wellman, C.H., A Companion to Applied Ethics. London, Blackwell.

Wootton, A. (1984), Insects of the World. United Kingdom: Blandford Press. Zimmerman, M.E. (Ed.) (1993), Environmental Philosophy. Englewood, Cliffs, New Jersey: Prentice Hall. 